\title{
Freshwater Raphidophyceae from the State of Rio de Janeiro, Southeast Brazil
}

\author{
Mariângela Menezes ${ }^{1,3}$ \& Carlos Eduardo de Mattos Bicudo ${ }^{2}$ \\ ${ }^{1}$ Laboratório de Ficologia, Museu Nacional, Universidade Federal do Rio de Janeiro - UFRJ, \\ Quinta da Boa Vista, São Cristóvão, CEP 20940-040, Rio de Janeiro, RJ, Brasil \\ ${ }^{2}$ Instituto de Botânica, \\ CP 3005, CEP 01061-970, São Paulo, SP, Brasil \\ ${ }^{3}$ Corresponding author: Mariângela Menezes, e-mail: menezesm@superig.com.br
}

MENEZES, M. \& BICUDO, C.E.M. Freshwater Raphidophyceae from the State of Rio de Janeiro, Southeast Brazil. Biota Neotrop. 10(3): http://www.biotaneotropica.org.br/v10n3/en/abstract?inventory+bn01510032010.

\begin{abstract}
This paper presents a floristic survey of Raphidophyceae (Heterokontophyta) found in three freshwater environments in the municipality of Rio de Janeiro, based on samples collected bimonthly from September 1988 to August 1991. A total of 117 samples were collected, and eight of these contained cells of raphidophytes. Altogether five raphidophyte species, representing the genera Gonyostomum (2), Merotrichia (1), and Vacuolaria (2) were identified. Four species are new records for the State of Rio de Janeiro (G. semen, G. depressum, M. bacillata, $V$. virescens var. virescens), and one is reported for the first time in Brazil (V. viridis). Gonyostomum semen and $V$. virescens var. virescens are the most widespread taxa in the area, found in 50 and $25 \%$ of the total of samples, respectively. With the exception of $M$. bacillata and $V$. viridis, most of the taxa occurred in a natural oligotrophic lake with acidic waters, in accordance with the preference of raphidophytes for low $\mathrm{pH}$. This study clearly supports the need for more extensive taxonomic surveys on these raphidophytes, based on field and cultured samples and under light and electron microscopy, to confirm the taxonomic identity of the previously reported species and to expand the knowledge of the taxa in Brazil. The bloom of G. semen reported here, together with its gradual dominance in the aquatic systems in the State of Rio de Janeiro seems to conform to the recent spread of this species into new areas, and can be viewed as a potential risk for environmental health.
\end{abstract}

Keywords: Gonyostomum, Vacuolaria, Merotrichia, flora, taxonomy, Rio de Janeiro, Brazil.

MENEZES, M. \& BICUDO, C.E.M. Raphidophyceae de água doce do Estado do Rio de Janeiro, Sudeste do Brasil. Biota Neotrop. 10(3): http://www.biotaneotropica.org.br/v10n3/pt/abstract?inventory+bn01510032010.

Resumo: Este trabalho apresenta o inventário florístico de Raphidophyceae (Heterokontophyta) encontradas em três corpos d'água doce no Município do Rio de Janeiro. Cento e dezessete amostras foram coletadas bimensalmente entre setembro de 1988 a agosto de 1988, das quais oito com representantes de rafidófitas distribuídas em duas espécies de Gonyostomum, uma de Merotrichia e duas de Vacuolaria. Quatro espécies constituem novos registros de ocorrência para o Estado do Rio de Janeiro (G. semen, G. depressum, M. bacillata, V. virescens var. virescens) e uma é citada pela primeira vez para o Brasil ( $V$. viridis). Gonyostomum semen e V. virescens var. virescens foram os táxons com maior distribuição na área de estudo totalizando 50 e $25 \%$ do total das amostras, respectivamente. Exceto $M$. bacillata e $V$. viridis, as demais espécies ocorreram principalmente em lago natural oligotrófico com águas ácidas reforçando a preferência do grupo a baixos valores de $\mathrm{pH}$. Este estudo suporta a necessidade de realizar inventários taxonômicos mais extensivos sobre rafidófitas a partir de amostras de campo e de cultura com base em microscopia ótica e eletrônica para confirmar a identidade taxonômica das espécies já registradas e ampliar o conhecimento do grupo no Brasil. A floração de G. semen registrada neste trabalho aliada a sua gradual dominância em ambientes aquáticos no Estado do Rio de Janeiro parece suportar a recente expansão dessa espécie em novas áreas e pode ser visto como um potencial risco a saúde do meio ambiente. Palavras-chave: Gonyostomum, Vacuolaria, Merotrichia, flora, taxonomia, Rio de Janeiro, Brasil. 


\section{Introduction}

Raphidophytes are unicellular biflagellate organisms that belong to the class Raphidophyceae in the division Heterokontophyta, and have both freshwater and marine representatives (Lee 2008). The raphidophytes show peculiar morphological and biochemical characteristics, which are the basis of their taxonomy. The cells are naked with numerous chloroplasts, and two subequal heterodynamic flagella emerge from the anterior part of the cell. The anterior flagellum is directed forward, has a tubular mastigoneme, and is responsible for the movement of the cell, whereas the trailing flagellum is smooth. A large nucleus and numerous mucocysts or trichocysts are present (Heywood 1980, 1982, 1990, Mignot 1967). The freshwater species contain diadinoxanthin, heteroxanthin, and vaucheriaxanthin, and the majority of marine species contain fucoxanthin and violaxanthin (Mostaert et al. 1998), with lightgreen and yellowish-brown chloroplast colors, respectively. The marine species Haramonas viridis Horiguchi \& Hoppenrath and H. pauciplastida Yamaguchi, Hoppenrath, Takishita \& Horiguchi have yellowish-green chloroplasts, but their pigment compositions are not yet known (Yamaguchi et al. 2009). The genus Chlorinimonas with a single species, $C$. sublosa Yamaguchi, Nakayama, Murakami $\&$ Inouye, has been described recently as a marine sand-dwelling raphydophycean; however, like the freshwater genera, it shows the presence of diadinoxanthine rather than fucoxathin (Yamaguchi et al. 2009). Members of this class can produce benthic resting cysts, which have been reported especially for the marine species (Imai \& Itoh 1987, Imai et al. 1991, Itakura et al. 1996) and only one freshwater species (Cronberg 2005, Figueiroa \& Rengefors 2006). Raphidophyte species can form massive blooms and are sometimes ichthyotoxic, causing large economic impacts worldwide (Bowers et al. 2006). Studies combining ultrastructural and molecular data based on SSU rDNA have indicated a paraphyletic relationship of marine yellowish raphidophytes and a monophyly of the freshwater raphidophytes (Potter et al. 1997, Yamaguchi et al. 2009). However, these studies are still insufficient, and the group remains poorly characterized, especially the freshwater raphidophytes; and its taxonomy is based only on morphological features. The raphidophytes encompass species belong to three freshwater genera (Gonyostomum, Merotrichia, and Vacuolaria) and five marine genera (Chattonella, Chlorinimonas, Fibrocapsa, Haramonas, and Heterosigma).

Research on raphidophytes, like other flagellate algal groups, does not have a long tradition in Brazil. Among the few publications are the studies on freshwater raphidophyceans of Skvortzov (1968), Skvortzov \& Noda (1968), Skvortvov et al. (1969), Bicudo \& Cardoso (1973), and Bicudo (1991). In this study, we report the results of a survey of raphidophytes from three lentic fresh water bodies located in the municipality of Rio de Janeiro, as a part of an ongoing taxonomic inventory of the pigmented phytoflagellates of Brazil. Investigations of silica-scaled chrysophytes, prasinophytes, and chlorophytes have been previously undertaken in the same environments (Menezes et al. 2005, Menezes \& Bicudo 2008).

\section{Material and Methods}

A total of 117 samples were collected in three lentic fresh water bodies in the Municipality of Rio de Janeiro, State of Rio de Janeiro, from September 1988 through August 1991, every two months: Lagoinha lagoon ( $23^{\circ} 02^{\prime} 23^{\prime \prime} \mathrm{S}$ and $\left.43^{\circ} 28^{\prime} 97^{\prime \prime} \mathrm{W}\right)$, a lake at Bosque da Barra (22 $59^{\prime} 02^{\prime}$ ' S and $\left.43^{\circ} 23^{\prime} 30^{\prime \prime} \mathrm{W}\right)$, and an unnamed oxbow pond by the side of the Avenida das Américas at Km 42 (22 $50^{\circ}$ ' $00^{\prime \prime} \mathrm{S}$ and $\left.43^{\circ} 38^{\prime} 55^{\prime} \mathrm{W}\right)$. Samples were taken from the shore by filling bottles directly with water and/or sediments, using a $25 \mu \mathrm{m}$ mesh size plankton net, or by hand-gathering macroscopic filamentous algae and cutting off submerged parts of macrophytes. The material was kept in bottles and maintained alive in laboratory for approximately three or four days. The cell membrane of this group is generally not preserved well by fixation with a general fixative due to the occurrence of osmotic changes as a result of fixation. Hence, the morphological analysis of algal cells in light microscopy has been carried out on living cells without fixation. After collection analysis, it was fixed and preserved with 3-5\% buffered formalin solution and included in the Coleção de Algas do Herbário do Museu Nacional (R).

The systematic arrangement of order and family essentially follows that recently proposed by Yamaguchi et al. (2009). The species concept applied was the morphospecies from natural samples. For more information on the study area and the techniques used, see Menezes (1994), Menezes et al. (2005) and Menezes \& Bicudo (2008).

\section{Results and Discussion}

Five raphidophycean species were found in eight samples collected in the three water bodies: two species of Gonyostomum, one of Merotrichia, and two of Vacuolaria. Among the identified species, G. semen, G. depressum, M. bacillata, V. virescens var. virescens are new records for the state of Rio de Janeiro, and $V$. viridis is reported for the first time in Brazil. No cysts were found in the sediment samples.

\section{RAPHIDOPHYCEAE CHADEFAUD EX SILVA 1980}

CHATTONELLALES Throndsen in Tomas 1993 emend. Yamaguchi et al. 2009

VACUOLARIACEAE Luther 1899 emend. Yamaguchi et al. 2009

\section{GONYOSTOMUM DIESING 1865}

Gonyostomum encompasses organisms with cells elliptical, obovoid or pyriform, sometimes rounded, with two apical flagella, a triangular or circular gullet, and needle-shaped trichocysts that are generally concentrated in one or both poles.

The apical flagellar insertion and the needle-like shape of the trichocysts distinguish Gonyostomum from Merotrichia and Vacuolaria, which have, respectively, subapical flagella and spherical mucocysts. According to Mignot (1967), the elongation of the trichocyst axis in Gonyostomum constitutes a very particular pattern, and is the only, although fundamental, difference from the mucocysts of Vacuolaria.

Genetic studies of Gonyostomum semen have been carried out by Figueiroa \& Rengefors (2006) and Yamaguchi et al. (2009), and showed that this species forms a distinct group with representatives of the two other freshwater genera, Vacuolaria virescens and Merotrichia bacillata.

Currently, four species have been recognized in the genus, most with a worldwide distribution in acidic waters (Kusber 2003).

\section{GONYOSTOMUM DEPRESSUM (LAUTERBORN) LEMMERMANN}

Krypt.-Fl. Brandenburg. 1908.

Basionym: Vacuolaria depressa Lauterborn in Zool. Anz. 19: 15. 1896

Synonym: Gonyostomum latum Iwanoff Bull. Nat. Moscou, 1899(4): 21, pl. 12, fig. 14-16. 1899. Figures 1-3.

Characteristics: Cells strongly deformable, (35-) 38-42 × (30-) $32-46 \mu \mathrm{m}$, flattened dorsoventrally, rounded in frontal view, sometimes angulate, dorsal side convex, ventral side concave, posterior pole usually truncate, rarely rounded. Chloroplasts 


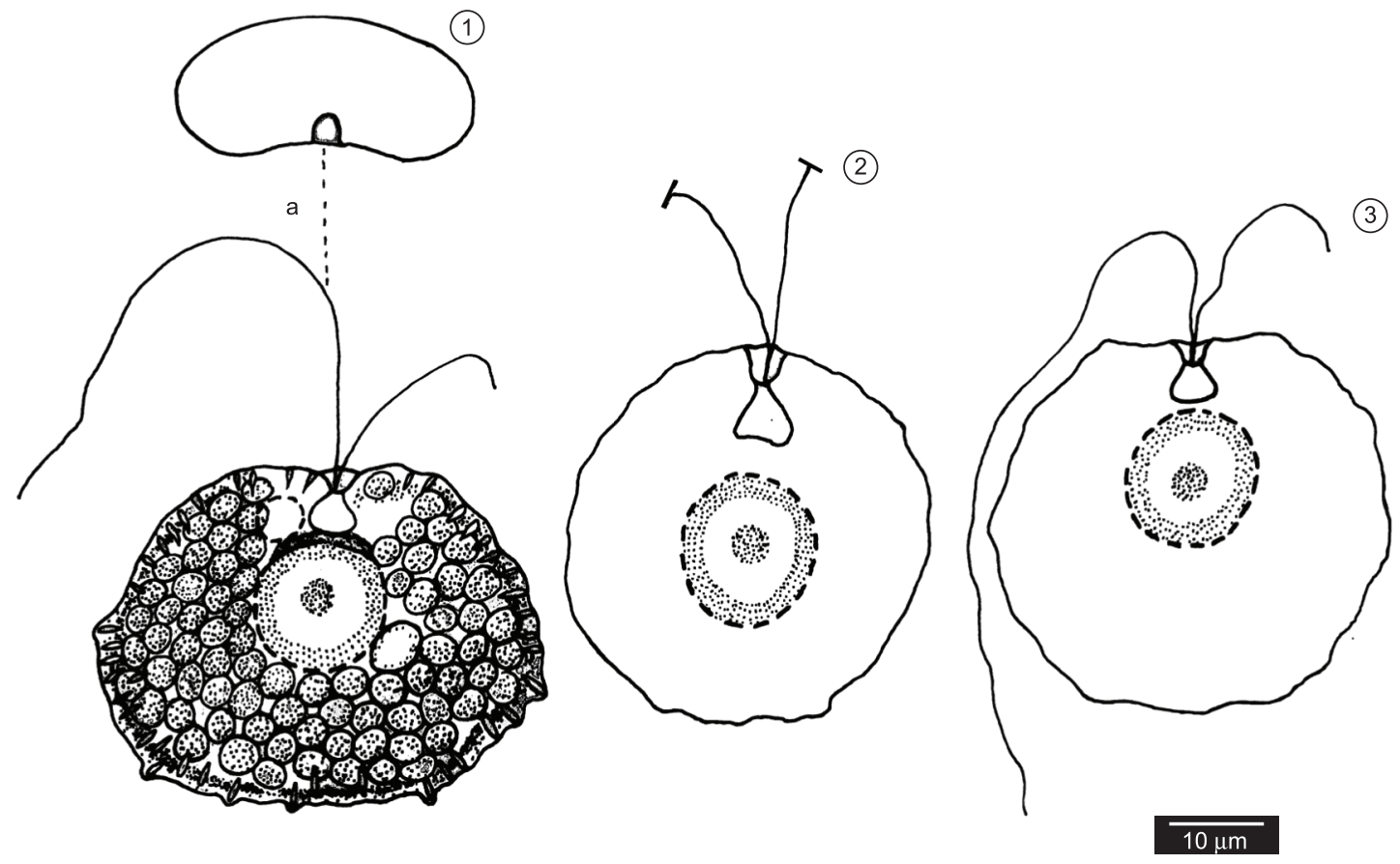

Figures 1-3. Gonyostoum latum. Figures 1- 3 lateral view. Figures. 1a apical view.

numerous, yellowish-green, discoid. One lipid globule near nucleus, ca. $5 \mu \mathrm{m}$ in diameter. Nucleus rounded, central, 13-15 $\mu \mathrm{m}$ in diameter. Mucocysts needle-like in shape, radially and homogeneously distributed. Gullet triangular. Contractile vacuoles 2, near gullet. Flagella apical, heterodynamic, anterior flagellum long, 2-2.5 times length of cell, posterior flagellum shorter, 0.2-0.5 times length of cell.

Material examined: BRAZIL, Rio de Janeiro: Lake at Bosque da Barra, coll. M. Menezes, 16.X.1989 (R173616).

Remarks: Kusber (2003) has designated as the lectotype of G. depressum the figure published in Lauterborn (1899, Figure 3e), formerly described as Vacuolaria depressa by Lauterborn (1896). Kusber (2003) agreed with Fott (1968) and Starmach (1974), and considered G. latum, described by Iwanoff (1900) without designation of a type, a heterotypic synonym of $G$. depressum; this name should have priority over G. latum.

The 30 cells analyzed perfectly agreed with the morphological features and dimensions described and illustrated for this species (Huber-Pestalozzi 1950, Starmach 1974). The cells were extremely deformable and very fragile, discharging the trichocysts with bursting of the cells by rupture of the membrane after fixation and after brief exposure to the light and heat of the microscope bulb.

Gonyostomum depressum is reported from Australia, Africa, Central America, Europe, and Japan (Kusber 2003). In Brazil this species has been previously reported as G. latum for the States of Piauí (Rodrigues et al. 2009), São Paulo (Dias Júnior 1990), and Rio Grande do Sul (Huszar 1977, 1984, Dewes \& Huszar 1986). Gonyostomum depressum was found in a plankton sample from the Bosque da Barra lake, together with euglenoids and Nephroselmis discoidea Skuja.

\section{GONYOSTOMUM SEMEN (EHRENBERG) DIESING}

Sber. Akad. Wiss. Wien, 52: 332. 1865.

= Monas semen Ehrenberg, Ber. Verh. k. preuss. Akad. Wiss. Berlin, 1833: 191. 1835. Figures 4-6.

Characteristics: Cells deformable, $45-60 \times 27-34 \mu \mathrm{m}$, slightly flattened dorsoventrally, obovoid or obpyriform in frontal view, dorsal and ventral sides convex, anterior pole sometimes slightly truncate, posterior pole usually pointed. Chloroplasts many, yellowish-green, discoid. Nucleus rounded, central, 10-13 $\mu \mathrm{m}$ in diameter. Trichocysts numerous, long and rod-like in shape, concentrated in poles of cell with a few others irregularly distributed in cytoplasm. Gullet triangular. Contractile vacuoles 1-2, near gullet. Flagella apical, unequal, heterodynamic, one directed forward and the other backward during swimming.

Material examined: BRAZIL, Rio de Janeiro: unnamed oxbow pond, coll. M. Menezes, 29.IX.88 (R172917); coll. M. Menezes and L.H.S. Silva, 30.IV.1990 (R173691); Lake at Bosque da Barra, coll. M. Menezes, 1.X.88 (R172925); coll. M. Menezes, 4.IX.89 (R173569).

Remarks: Gonyostomum semen (Ehrenberg) Diesing is easily recognized by the dorsoventrally flat obovoid cells with a pointed posterior pole, and by the large number of trichocysts located at the cell poles. These characters distinguish this species from G. ovatum Fott and G. intermedium Skuja, which have elliptical cells and more trichocysts in the posterior or anterior poles, respectively.

One hundred cells from the three different populations were examined, and had exactly the vegetative morphological and dimensional features described in the literature (HuberPestalozzi 1950, Mignot 1967, Cronberg 2005, Figueiroa \& 


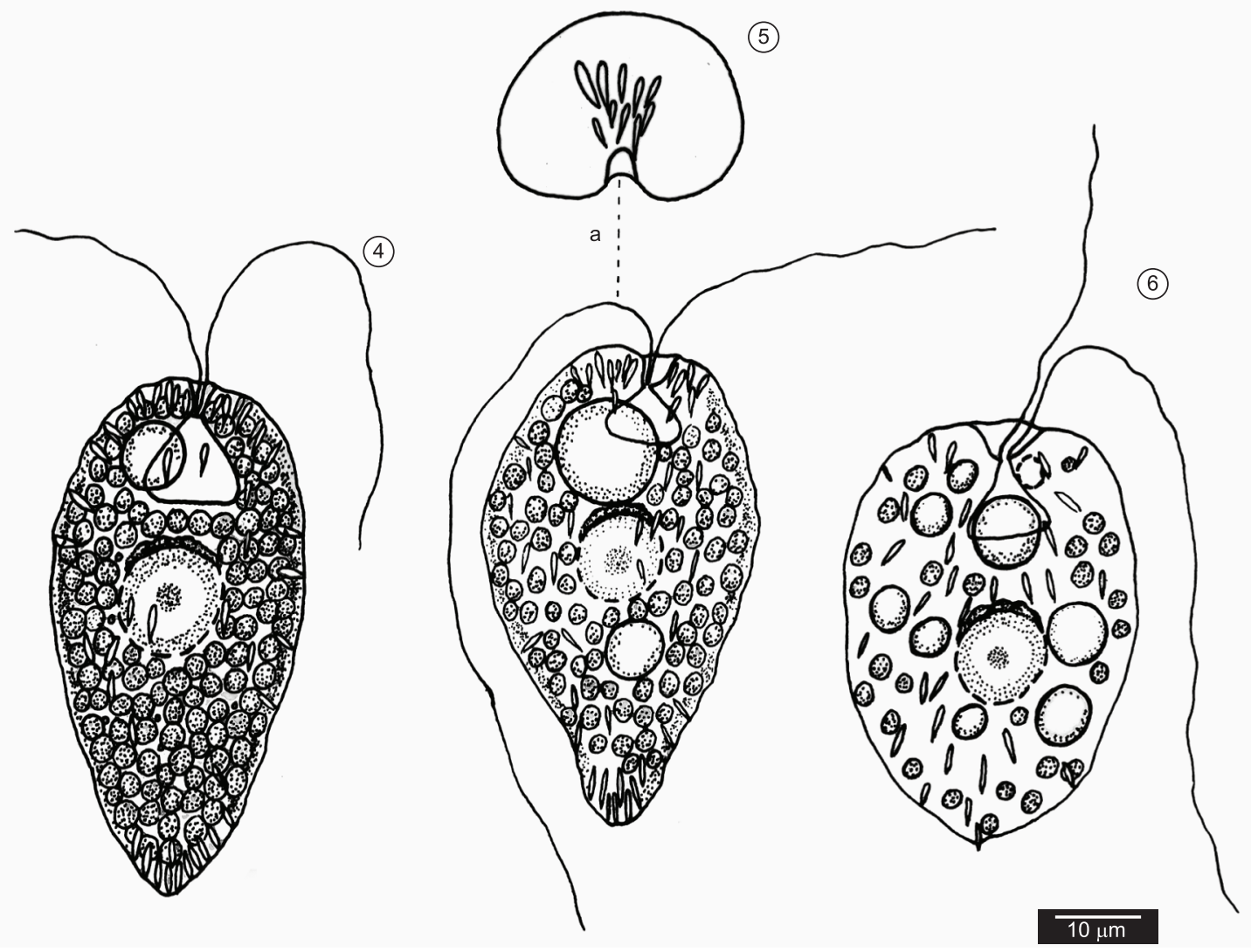

Figures 4-6. Gonystomum semen. Figures 4-6 lateral view. Figure 5a apical view.

Rengefors 2006). In general, the cells were typically obpyriform during swimming, with a slight metaboly; when stopped, the cells exhibited the posterior pole pointed. Frequently, cells fixed in $2.5 \%$ of paraformaldehyde solution had their posterior pole rounded, becoming obovoid (Figure 6). Most of the cells discharged their trichocysts after fixation, consequently bursting by rupture of the membrane.

Gonyostomum semen is the most common freshwater raphidophycean, and has been widely reported from Africa, Asia, Europe, and North and South America (Gustafsson et al. 2009). This species often forms blooms in slightly acidic waters, and emits a slimy substance that causes skin irritation and allergic reactions. This phenomenon has led to the temporary closure of a number of freshwater recreational sites (Cronberg et al. 1988, Rengefors et al. 2008, Willén 2003). In recent decades, G. semen has rapidly increased its distribution and abundance in lakes in Northern Europe (Gustafsson et al. 2009).

In Brazil, this species has been reported as dominant in a tropical humic coastal lagoon in Northeastern Rio de Janeiro, where it comprised up to $31 \%$ of the phytoplankton biomass (Alves-de-Souza et al. 2006). It has also been observed since 2008 as a dominant species in an artificial eutrophic channel located at the Quinta da Boa Vista, city of Rio de Janeiro, with concentrations of up to $1.2 \times 10^{2}$ cells. $L^{-1}$ during the summer (unpublished data). Gonyostomum semen occurred in plankton and sediment samples from the oxbow pond and Bosque da Barra lake, always together with cryptomonads. It was the most frequent species in the area, occurring in $50 \%$ of the samples that contained raphidophytes.
A bloom of this species with cell concentrations of $2.2 \times 10^{6}$ cells. $\mathrm{L}^{-1}$ (90\% of the phytoplankton biomass) was observed in April 1989 in the Bosque da Barra, a shallow humic artificial lake. We have no additional information on the occurrence of blooms of this species in other localities in Brazil.

\section{GENUS MEROTRICHIA MERESCHKOWSKY 1877}

Merotrichia is characterized by the elliptical or pyriform cell with the anterior pole frequently capitate, by the long rod-shaped trichocysts located in the anterior pole, and by the subapical insertion of the flagella. This last feature distinguishes Merotrichia from Gonyostomum, which has apically inserted flagella.

The genus encompasses one species, M. bacillata Mereschkowsky. Merotrichia capitata Skuja and the genus Palmeriamonas, described from material from São Paulo by Skvortzov (1968), are considered heterotypic synonyms of M. bacillata (Starmach 1974, Bicudo 1991).

\section{MEROTRICHIA BACILLATA MERESCHKOWSKY}

Trudy leningr. Obshch. Estest., 8: 291. pl. 2, fig. 18. 1877. Figures 7-9.

Characteristics: Cells slightly deformable, 40-48 $\times 20$ $23 \mu \mathrm{m}$, obpyriform in frontal view, elliptic to obovoid in lateral view, anterior pole capitate. Chloroplasts numerous, bright green, discoid. Nucleus rounded, central, 9-15 $\mu \mathrm{m}$ in diameter. Trichocysts long and rod-like, concentrated in anterior pole of cell, radially arranged. Gullet triangular. Flagella subapical, heterodynamic, anterior flagellum shorter, 0.5-0.8 times length of cell, and posterior flagellum longer, almost same length as cell. 

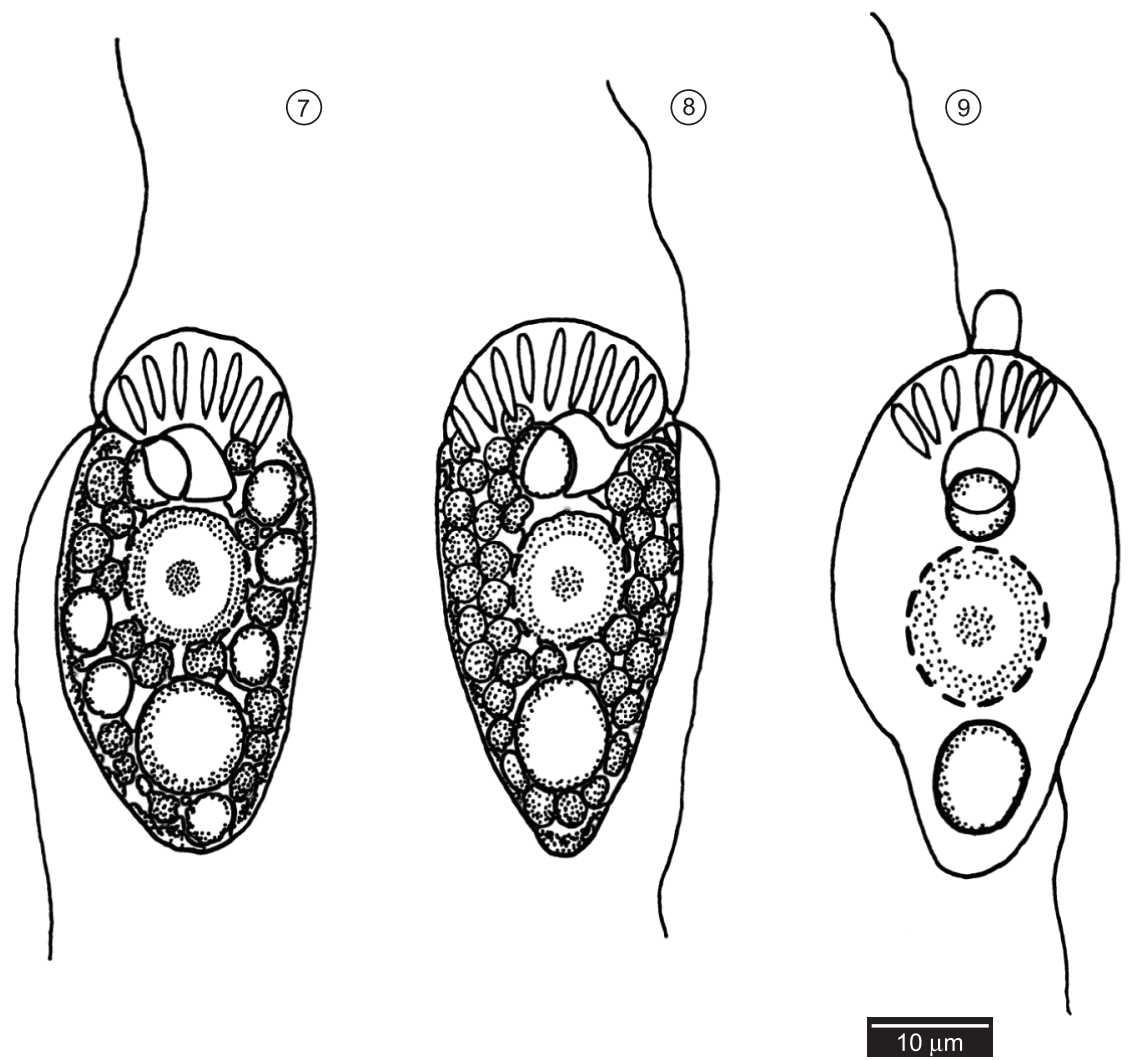

Figures 7-9. Merotrichia bacillata. Figures 7-8 lateral view. Figure 9 dorsal view.

Material examined: BRAZIL, Rio de Janeiro: unnamed oxbow pond, coll. M. Menezes, 27.VIII.1990 (R173758).

Remarks: The 20 specimens analyzed agreed with the definition of the species (Mereschkowsky 1877, Huber-Pestalozzi 1950, Starmach 1974). Most individuals were weakly metabolic and more resistant than other raphidophycean species under the action of chemical fixation and the light and heat of a microscope bulb; a few cells $(<5 \%$ of the total $)$ discharged their trichocysts, with rupture of the membrane.

Merotrichia bacillata is reported from Australia, Europe, North America, and Tasmania (Croome \& Tyler 1988, Ott \& Oldamnn-Ott 2003, Kobayashi et al. 2005, Willen 1992). In Brazil, it has been previously reported from the states of Rio de Janeiro (Alves-de-Souza et al. 2006) and São Paulo (Skvortzov 1968 as Palmeriamonas planctonica Skvortzov, Skvortzov 1969 et al. as M. capitata, Bicudo 1991). The species occurred in one plankton sample from an oxbow pond.

Genus Vacuolaria Cienkowski, 1870.

The genus comprises organisms with cells usually elliptical and two apical flagella, a circular gullet, and regularly distributed granular mucocysts.

The delimitation of Vacuolaria species is somewhat controversial. Some authors believe that Vacuolaria encompasses a single species, represented by V. virescens (Spencer 1971); while others have recognized the autonomy of approximately seven species (Heywood 1980, Bicudo 1991). According to Spencer (1971), some diagnostic characters such as the cell shape, length of the flagella, and the degree of cell deformation can vary under different environmental conditions. On the other hand, studies of the chromosome number in Vacuolaria have revealed differences among some species, e.g., approximately 30 chromosomes in $V$. viridis (Dangeard) Senn (Fott 1935) and 20 in V. virescens (Spencer 1971, Heywood 1980). Heywood \& Godward (1973) found chromosome numbers of the latter species ranging from 97 to 99 , and noted that these results and the higher chromosome number of $V$. virescens could the result of polyploidy in cells, caused by the old age of the cultures studied. For this genus, genetic sequencing has been conducted only for V. virescens (Daugbjerg \& Andersen 1997, Potter et al. 1997, Ben Ali et al. 2002), and consequently there are problems in classification and identification of the species belonging to this genus, as for the other freshwater raphidophycean genera.

\section{VACUOLARIA VIRESCENS CIENKOWSKI VAR. VIRESCENS}

Arch. mikrosk. Anat. Entwmech., 6: 426. pl. 23, fig. 1870. Figures 10-11

Characteristics: Cells slightly deformable, 37-53 $\times 25$ $38 \mu \mathrm{m}$, flattened dorsoventrally, ovoid to elliptical in frontal view. Chloroplasts numerous, discoid, bright green. One lipid globule in posterior part of cell, ca. $5 \mu \mathrm{m}$ in diameter. Nucleus rounded, central, 12-15 $\mu \mathrm{m}$ in diameter. Many granular, spherical, regularly distributed mucocysts. Gullet circular. Flagella apical, heterodynamic, anterior flagellum longer, equal to 1.5 times cell length, posterior flagellum smaller, 0.2-0.5 times cell length.

Material examined: BRAZIL, Rio de Janeiro: Lake at Bosque da Barra, coll. M. Menezes, 1.X.1988 (R172923); coll. M. Menezes, 21.II.90 (R173663).

Remarks: Vacuolaria virescens Cienkowski is distinguished from other cells of the genus by the cells varying from elliptical or ovoid 


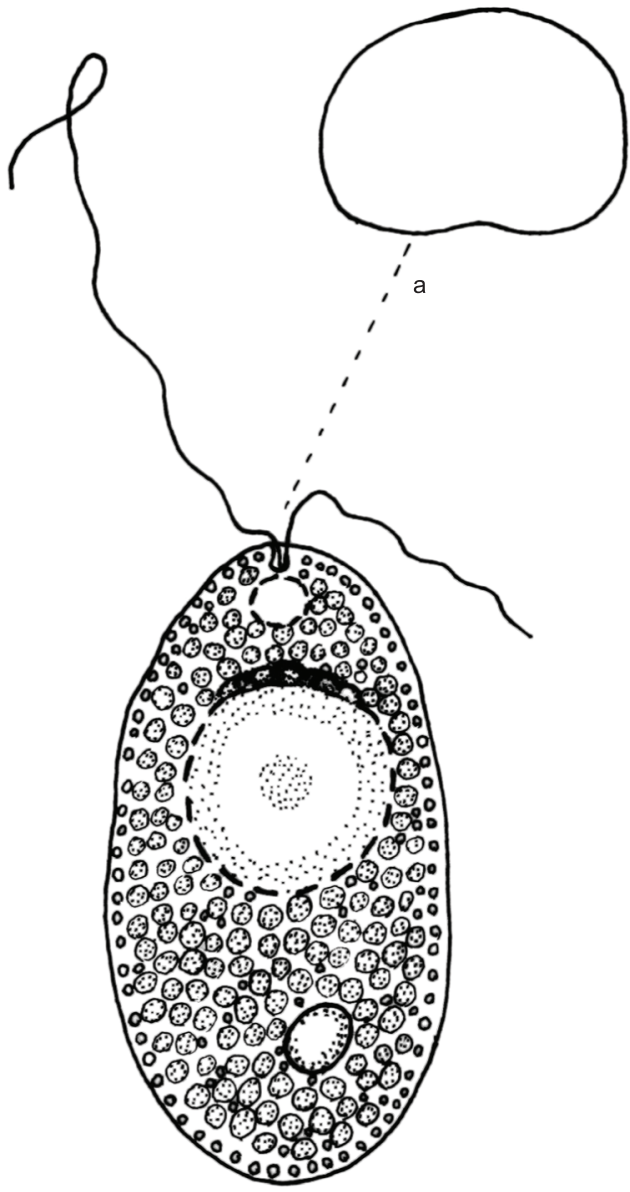

(10)

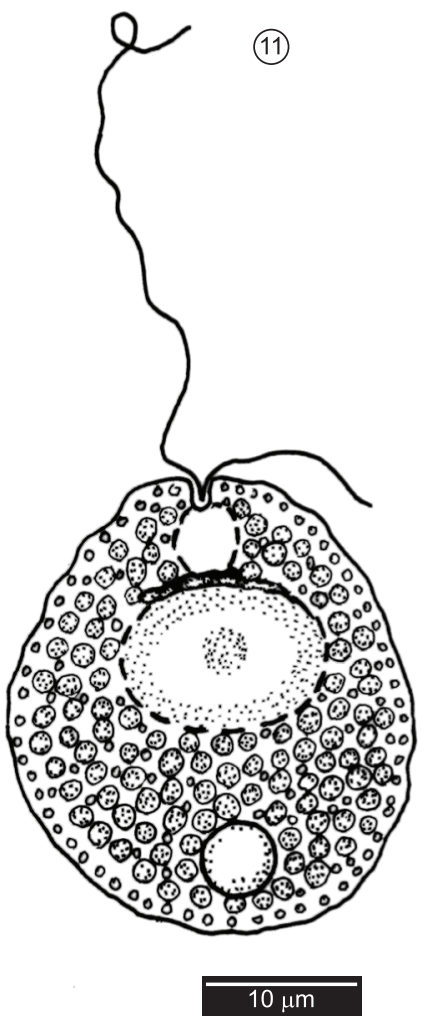

Figures 10-11. Vacuolaria virescens var. virescens. Figures 10-11 lateral view. Figure 10a) apical view.

to oblong, and by the homogeneous distribution of the chloroplasts in the protoplasm. Vacuolaria penardii Fott has elliptical-ovoid to cylindrical cells and chloroplasts concentrated in the central cell region, whereas $V$. viridis (Dangeard) Senn has cells that are heart-shaped or obpyriform, strongly flattened dorsiventrally. Vacuolaria viridis was also distinguished from $V$. virescens based on the chromosome number reported in the literature (Fott 1935, Spencer 1971, Heywood 1980), 30 and 20, respectively.

Bicudo \& Cardoso (1973) described V. tropicalis C. Bicudo \& Cardoso based on material from the state of São Paulo, separating this taxon from $V$. virescens by the spherical, sometimes elliptical or ovoid cell and by the grass-green color of the chloroplasts. Later, Bicudo (1991) again distinguished V. tropicalis from $V$. virescens, particularly by the presence of short rod-shaped versus granular mucocysts, respectively.

Apparently, the diagnostic features of $V$. tropicalis do not show clear differences from $V$. virescens. The original descriptions of both species indicate that they are variable in cell shape, with overlapping morphology due to their metaboly, and the presence of granular mucocysts. Furthermore, other findings have described $V$. virescens with green chloroplasts (e.g., Coleman \& Heywood 1981 , this study). Additional studies of $V$. tropicalis are essential to clarify its taxonomic identity, particularly because this taxon is known only from its type locality. Similar questions extend to the other species of Vacuolaria, since there are many problems concerning the delimitation of species, as indicated above in the genus description.

Fifty cells were examined, which agreed with $V$. virescens var. virescens (Fott 1970, Starmach 1974). We did not observe any morphological variability, except during metaboly when the cells became more rounded (Figure 11).

The population from Rio de Janeiro differs from $V$. virescens var. virescens reported by Bicudo (1991) by the presence of short rod-shaped mucocysts in the latter.

Vacuolaria virescens has been reported from China, Europe, Japan, and the United States. In Brazil, the species was reported from the State of São Paulo by Skvortzov \& Noda (1968, as V. fusiformis and V. skujae) and Bicudo (1991). In this study, $V$. virescens var. virescens was found only in the lake at Bosque da Barra, where it was collected from plankton and sediment samples together with euglenoids and dinoflagellates.

\section{VACUOLARIA VIRIDIS (DANGEARD) SENN}

In Engler \& Prantl, Naturl. PflFam., 2: 172. 1900.

$\equiv$ Anisonema viride Dangeard, Botaniste, 1(1):1889. Figures 12-13.

Characteristics: Cells strongly deformable, 30-40 ×22-26 $\mu \mathrm{m}$, flattened dorsoventrally, heart-like shape to obpyriform in frontal view, dorsal side convex, ventral side slightly concave. Chloroplasts numerous, yellowish-green, discoid. Sometimes a single lipid globule near the nucleus, 3-5 $\mu \mathrm{m}$ in diameter. Nucleus 

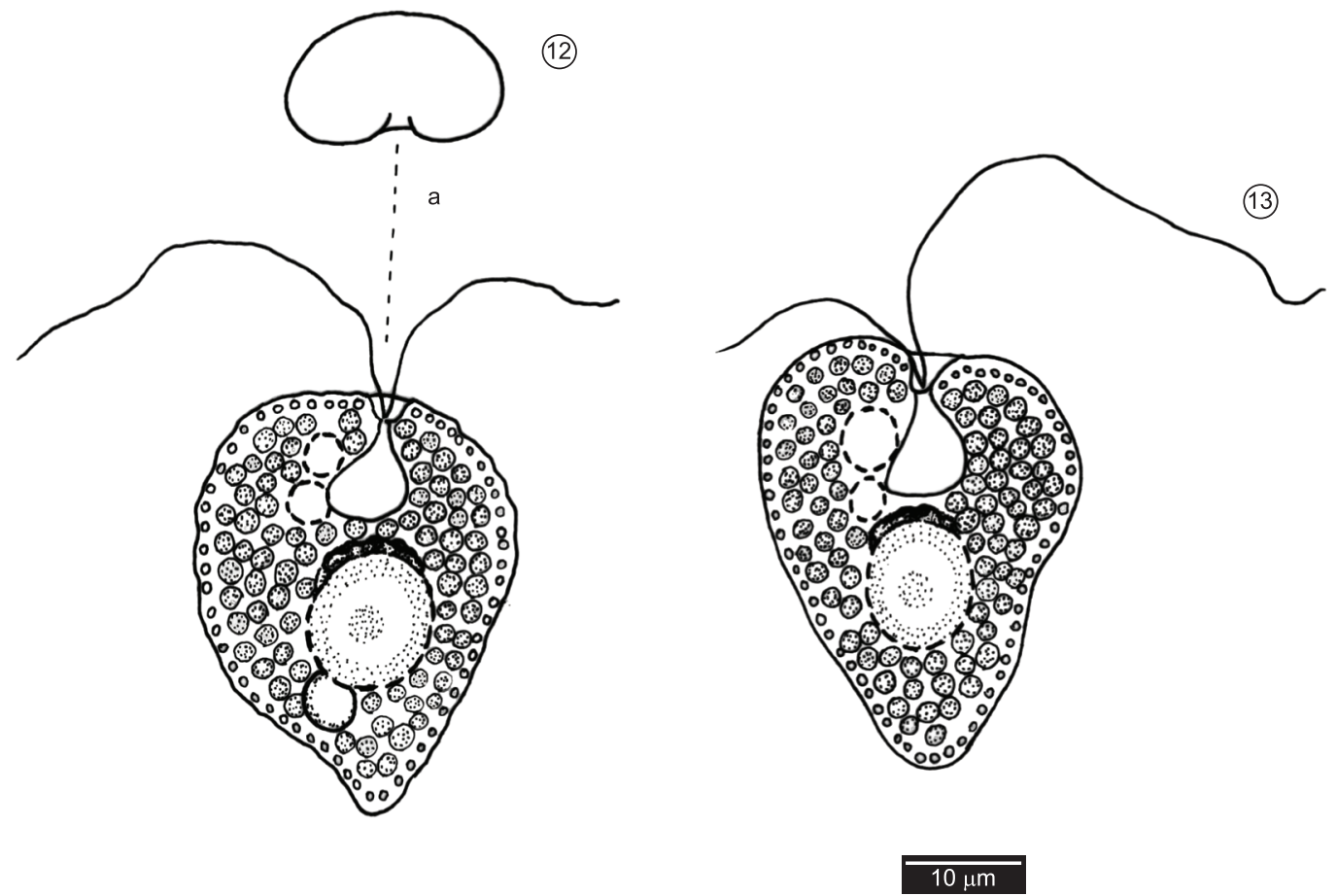

Figures 12-13. Vacuolaria viridis. Figures 12-13 lateral view. Figure 12a) apical view.

rounded, central, 10-15 $\mu \mathrm{m}$ in diameter. Mucocysts many, granular, spherical, regularly distributed. Gullet triangular. Two contractile vacuoles near gullet. Flagella apical, unequal, heterodynamic, anterior flagellum longer, 1-1.5 times length of cell, and posterior flagellum shorter, 0.5-0.7 times length of cell.

Material examined: BRAZIL, Rio de Janeiro: Lagoinha, coll. M. Menezes and I. C. A. Dias, 27.III.89 (R173470).

Remarks: As noted above, we considered $V$. viridis as distinct from $V$. virescens, by the cell shape and chromosome number.

In the present material, the cells were smaller than the dimensions reported in the literature, which are 42-60 × 31-39 $\mu \mathrm{m}$ (HuberPestalozzi 1950, Skvortzov \& Noda 1968, Starmach 1974). The cells were strongly deformable and frequently exploded by discharge of their mucocysts after fixation and under the light and heat of the microscope.

Vacuolaria viridis has been reported from Europe. New to Brazil. Vacuolaria viridis occurred once in a Lagoinha plankton sample, together with euglenoids and cryptomonads.

The use of morphological features to distinguish raphidophyte species is very difficult, because of their pleomorphology that changes shape and size with the environmental conditions, as well as the state and age of the cell (Demura et al. 2009, Khan et al. 1995). However, there are few recent studies based on advanced molecular and genetic tools, and the morphological differences are still used in the taxonomy of this group. Ultrastructural studies have supported the taxonomic value of morphology for some raphidophytes from marine habitats (Hara \& Chiara 1985, 1987, Mignot 1976), and more rarely from freshwater (Mignot 1967). A recent study including molecular data has reinforced the validity of morphological features in the delimitation of marine genera and species of raphidophytes; and also showed, based on SSU rDNA sequences, that the three freshwater genera Gonyostomum semen, Merotricha bacillata, and Vacuolaria virescens are monophyletic and form a distinct clade from the other genera (Yamaguchi et al. 2009).
In our study, the five taxa of raphidophytes could be clearly defined based on the traditional morphological criteria: the insertion of the flagella and the shape of the extrusomes (mucocysts or trichocysts) for the delimitation of the genera, and the distribution pattern of the extrusomes for the circumscription of the species.

Similarly, cell shape and size were adequate for delimitation of species of Gonyostomum (G. depressum and G. semen) and of Vacuolaria ( $V$. virescens and $V$. viridis). However, features such as trichocyst shape and chloroplast color should be better evaluated in the delimitation between $V$. virescens and $V$. tropicalis, the latter described from São Paulo material.

The low rate of occurrence of raphidophytes in all 132 samples collected was expected, since the group is recognized as typical of humic-rich systems, especially from high altitudes (Cronberg et al. 1988, Hehmann et al. 2001, Findlay et al. 2005). In the present study, the largest number of taxa (three) was found in a lake at Bosque da Barra, with oligotrophic waters and $\mathrm{pH}$ ranging from 5.5 to 6.5. Raphidophytes were also dominant in the lake at Bosque da Barra with respect to the number of samples, occurring in 5 of the 8 samples taken.

Gonyostomum semen was the most widespread taxon in the area, occurring in $50 \%$ of the samples that contained raphidophytes, and formed an extensive bloom in the Bosque da Barra Lake in April 1989. This species has a worldwide distribution, and is found mostly in humic lakes where it can form nuisance blooms, especially during late summer (Rengefors et al. 2008). However, in recent decades, G. semen has increased its distribution and abundance, including non-humic and more eutrophic systems (Cronberg 2005, Pęczuła 2007, Rengefors et al. 2008). Importantly, this species has been recorded as dominant in two other environments in the state of Rio de Janeiro: a coastal humic environment (Alves-de-Souza et al. 2006) and an artificial eutrophic channel (unpublished data). There are many hypotheses to explain the recent expansion of $G$. semen, e.g., the effect of water acidification (Cronberg et al. 1988), increasing eutrophication (Lepistö \& Saura 1998), and climate changes (Rengefors et al. 2008). However, there is 
little information about the ecology of this species, and consequently the factors that have promoted its expansion remain unknown.

In summary, this study broadened the known geographical distribution of raphidophytes in Brazil, and clearly supports the need for more extensive taxonomic surveys on this group, since only a few sites in the country have been investigated. Studies should be carried out using field and cultured samples and under light and electron microscopy, aiming to confirm the taxonomic identity of the taxa in Brazil.

The bloom of G. semen reported in this work, associated with its gradual dominance in the aquatic systems in the State of Rio de Janeiro during the last 20 years, seems to conform to the pattern of the recent spread of this species into new areas. It may be viewed as a potential risk for environmental health and an impetus for future investigations of the pattern of this expansion, particularly in tropical areas.

\section{Acknowledgments}

Janet W. Reid (JWR Associates) revised the English text. This research was funded by Capes and CNPq.

\section{References}

ALVES-DE-SOUZA, C., MENEZES, M. \& HUSZAR, V.L.M. 2006. Phytoplankton composition and functional groups in a tropical humic coastal lagoon, Brazil. Acta Bot. Bras. 20(3):701-708.

BEN ALI, A., DE BAERE, R., DE WACHTER, R. \& VAN DE PEER, Y. 2002. Evolutionary relationships among heterokont algae (the autotrophic stramenopiles) based on combined analyses of small and large subunit ribosomal RNA. Protist 153(2):123-132.

BICUDO, C.E.M. \& CARDOSO, M.B. 1973. Vacuolaria tropicalis. A new species of Chloromonad from southern Brazil. Eur. J. Phycol. 8(4):339-342.

BICUDO, C.E.M. 1991. Criptógamos do Parque Estadual das Fontes do Ipiranga, São Paulo, SP. Algas, 1: Chloromonadophyceae. Hoehnea 18:77-85.

BOWERS, H.A., TOMAS, C., TENGS, T., KEMPTON, J.W., LEWITUS, A.J. \& OLDACH, D.W. 2006. Raphidophyceae [Chadefaud ex Silva] systematics and rapid identification: sequence analyses and real-time PCR assays. J. Phycol. 42:1333-1348.

COLEMAN, A.W. \& HEYWOOD, P. 1981. Structure of the chloroplast and its DNA in chloromonadophycean algae. J. Cell Set. 49:401-409.

CRONBERG, G. 2005. The life cycle of Gonyostomum semen (Raphidophyceae). Phycologia 44:285-293.

CRONBERG, G., LINDMARK, G. \& BJÖRK, S. 1988. Mass development of the flagellate Gonyostomum semen (Raphidophyeae) in Swedish forest lakes - an effect of acidification? In Flagellates in Freshwater Ecosystems (R.I. Jones \& V. Ilmavirta, eds). Kluwer Academic Publishers, Netherlands, p. 217-236.

CROOME, R.L. \& TYLER, P.A. 1988. Phytoflagellates and their ecology in Tasmanian polyhumic lakes. Hydrobiologia 161:245-253.

DAUGBJERG, N. \& ANDERSEN, R.A. 1997. A molecular phylogeny of the heterokont algae based on analyses of chloroplast-encoded rbcL sequence data. J. Phycol. 33:1031-1041.

DEMURA, M., NOEL, M.H., KASAI, F., WATANABE, M.M. \& KAWACHI, M. 2009. Taxonomic revision of Chattonella antiqua, C. marina and $C$. ovata (Raphidophyceae) based on their morphological characteristics and genetic diversity. Phycologia 48(6):518-535.

DEWES, J. \& HUSZAR, V.L.M. 1986. Influência dos despejos lançados na Sanga da Barbuda sobre as águas do Lago da Barragem Santa Barbara, Pelotas, RS. In Algas: energia do amanhã. (C.E.M. Bicudo, A.C. Teixeira \& J.G. Tundisi, eds.). Instituto Oceanográfico, São Paulo, p. 141-161.
DIAS JÚNIOR, C. 1990. Ciclo anual do fitoplâncton e algumas variáveis ambientais na Lagoa do Infernão (SP). Dissertação de mestrado, Universidade Federal de São Carlos, São Carlos.

FIGUEROA, R.I. \& REGEFORS, K. 2006. Life cycle and sexuality of the freshwater raphidophyte Gonyostomum semen (Raphidophyceae). J. Phycol. 42:859-871.

FINDLAY, D.L., PATERSON, M.J., HENDZEL, L.L. \& KLING, H.J. 2005. Factors influencing Gonyostomum semen blooms in a small boreal reservoir lake. Hydrobiologia 533:243-252

FOTT, B. 1968. Chloromonadophyceae. In Das Phytoplankton des Süßwassers 3(2) (G. Huber-Pestalozzi, ed.). E. Schweizerbart'sche Verlagsbuchandlung, Stuttgart, p. 79-93.

FOTT, B. 1935. Über den inneren Bau von Vacuolaria viridis (Dangeard) Senn. Arch. Protistenk. 84:242-250.

FOTT, B. 1970. Taxonomische Übertragungen und Namensänderungen unter den Algen III. Chloromonadophyceae. Preslia 42:16-20.

GUSTAFSSON, S., HULTBERG, M., FIGUEROA, R.I. \& RENGEFORS, K. 2009. On the control of HAB species using low biosurfactant concentrations. Harmful Algae 858:857-863.

HARA, Y. \& CHIHARA, M. 1985. Ultrastructure and taxonomy of Fibrocapsa japonica (Class Raphidophyceae). Arch. Protistenk. 130:133-141.

HARA, Y. \& CHIHARA, M. 1987. Morphology, ultrastructure and taxonomy of the raphidophycean alga Heterosigma akashiwo. Bot. Mag. Tokyo 100:151-163.

HEHMANN, A., KRIENITZ, L. \& KOSCHEL R. 2001, Long-term phytoplankton changes in an artificially divided, top-down manipulated humic lake. Hydrobiologia 448:83-96

HEYWOOD, P. \& GODWARD, M.B.E. 1973. Chromosome number and morphology in Vacuolaria virescens (Chloromonadophyceae). Ann. Bot. 37:423-425.

HEYWOOD, P. 1980. Chloromonads. In Phytoflagellates: Developments in Marine Biology. (E.R. Cox, ed.). Elsevier, New York, p. 351-379.

HEYWOOD, P. 1982. Raphidophyceae (Chloromonadophyceae): introduction and bibliography. In Select papers in Phycology 2 (S.R. Rosowski \& B.C. Parker, eds.). Phycological Society of America, Lawrence, Kansas, p. 719-722.

HEYWOOD, P. 1990. Phylum Raphidophyta. In Handbook of Protoctista (L. Margulis, J.O. Corliss, M. Melkonian \& D.J. Chapman, eds). Jones \& Bartlett, Boston, p. 318-325.

HUBER-PESTALOZZI, G. 1950. Das Phytoplankton des Süsswassers: Systematik und Biologie. Schweizerbart'sche Verlagsbuchandlung, Stuttgart, 310p. Die Binnengewässser 16(3).

HUSZAR, V.L.M. 1977. Contribuição ao conhecimento das algas planctônicas do Lago da Barragem Santa Bárbara, Pelotas, Rio Grande do Sul, Brasil. Dissertação de Mestrado, Universidade Federal do Rio Grande do Sul, Porto Alegre.

HUSZAR, V.L.M. 1984. Contribuição ao conhecimento das algas planctônicas do Lago da Barragem Santa Bárbara, Pelotas, Rio Grande do Sul, Brasil. Phycol. Lat.-Amer. 2:169-201.

IMAI, I. \& ITOH, K. 1987. Annual life cycle of Chattonella spp., causative flagellates of noxious red tides in the Inland Sea of Japan. Mar. Biol. 94:287-292.

IMAI, I., ITAKURA, S. \& ITOH, K. 1991. Life cycle strategies of the red tide causing flagellates Chattonella (Raphidophyceae) in the Seto Inland Sea. Mar. Poll. Bull. 23:165-170.

ITAKURA, S., NAGASAKI, K., YAMAGUCHI, M. \& IMAI, I. 1996. Cyst formation in the red tide flagellate Heterosigma akashiwo (Raphidophyceae). J. Plank. Res. 18:1975-1979.

IWANOFF, L. 1900. Ueber neue Arten von Algen und Flagellaten (Stigeoclonium, Vaucheria, Spirogyra, Gonyostomum), welche an der biologischen Station zu Bologoje gefunden worden sind. Bull. Soc. Imp. Nat. Moscou, ser. 2, 13:423-449.

KOBAYASHI, T., SANDERSON, B.G. \& GORDON, G.N.G. 2005. A phytoplankton community in a temperate reservoir in New South Wales, 
Australia: relationships between similarity and diversity indices and measures of hydrological disturbance. Mar. Fresh. Res. 56(2):203-214.

KUSBER, W.-H. 2003. Typification of the four European species of Gonyostomum (Raphidophyceae) and first records of G. depressum from NE Germany. Willdenowia 33:467-474.

LAUTERBORN, R. 1896. Diagnosen neuer Protozoen aus dem Gebiete des Oberrheins. Zool. Anz. 19:14-18.

LAUTERBORN, R.1899. Protozoenstudien IV. Flagellaten aus dem Gebiete des Oberrheins. Z. Wiss. Zool. 65: 369-391.

LEE, R. E. 2008. Phycology. Cambridge University Press, New York.

LEPISTÖ, L. \& SAURA, M. 1998. Effects of forest fertilisation on phytoplankton in a boreal brown-water lake. Boreal Env. Res. 3:33-43.

MENEZES, M. \& BICUDO, C.E.M. 2008. Flagellate green algae from four water bodies in the state of Rio de Janeiro, Southeast Brazil. Hoehnea 35(3):435-468

MENEZES, M. 1994. Fitoflagelados pigmentados de quatro corpos d'água da região sul do município do Rio de Janeiro, Estado do Rio de Janeiro, Brasil. Tese de Doutorado, Universidade de São Paulo, São Paulo.

MENEZES, M., KRISTIANSEN, J. \& BICUDO, C.E.M. 2005. Silica-scaled chrysophytes from some tropical freshwater bodies, Southeastern Brazil. Nova Hedwigia 128:85-100.

MERESCHKOWSKY, C. 1877. Studien über Protozoen des nördlichen Russland.Trudy leningr. Obshch. Estest. 8: 203-385.

MIGNOT, J.-P. 1967. Structure et ultrastructure de quelques Chloromonadines. Protistologica 3:5-24.

MIGNOT, J.-P. 1976. Compléments a l'étude des Chloromonadines. Ultrastructure de Chattonella subsalsa Biecheler flagella d'eau saumâtre. Protistologica 12:279-293

MOSTAERT, A.S., KARSTEN, U., HARA, Y. \& WATANABE, M.M. 1998. Pigments and fatty acids of marine raphidophytes: a chemotaxonomic re-evaluation. Phycol. Res. 46:213-220.

OTT, D.W. \& OLDHAM-OTT, C.K. 2003. Eustigmatophyceae, Raphidophyceae, and Tribophyceae. In Freshwater Algae of North America (J.D. Wehr \& R.G. Sheath eds). Academic Press, San Diego, p. 423-469.

PECZUŁA, W. 2007. Mass development of the algal species Gonyostomum semen (Raphidophyceae) in the mesohumic Lake Płotycze (central-eastern Poland). Int. J. Ocean. Hydrobiol. 36(1):163-172.
POTTER, D., SAUNDERS, G. W. \& ANDERSEN, R. A. 1997. Phylogenetic relationships of the Raphidophyceae and Xanthophyceae as inferred from nucleotide sequences of the $18 \mathrm{~S}$ ribosomal RNA gene. Am. J. Bot. 84:966-972.

RENGEFORS, K., PÅLSSON, C., HANSSON, L.-A. \& HEIBERG, L. 2008. Cell lysis of competitors and osmotrophy enhance growth of the bloomforming alga Gonyostomum semen. Aquat. Microb. Ecol. 51:87-96.

RODRIGUES, E.I., GONÇALVES, F.C.M., MOURA, M.R., SILVA, R., LEAL, C.B. \& FIGUEIREDO, F.J. 2009. Composição floristica da comunidade fitoplanctônica de poças d'água localizadas ao longo de um córrego sobre inselbergs de arenito da Formação Cabeças, na região de Picos, Piauí, Brasil. In Anais do IX Congresso de Ecologia do Brasil. São Lourenço, MG. www.seb-ecologia.org.br/2009/resumos_ixceb/1092.pdf

SKVORTZOV, B.V. \& NODA, M. 1968. On Brazilian and European species of genus Vacuolaria. J. Jap. Bot. 43(3):69-76.

SKVORTZOV, B.V. 1968. Um novo gênero de flagelado verde de São Paulo: Palmeriamonas, gênero nov., Pyrrophyta. Notas Algologicas 2:1-9.

SKVORTZOV, B.V., BICUDO, C.E.M. \& BICUDO, R.M.T. 1969. First report of the occurrence of Chloromonadophyceae in Brazil. Rickia 4:93-98.

SPENCER, L.B. 1971. A study of Vacuolaria virescens Cienkowski. J. Phycol. 7:274-279.

STARMACH, K. 1974. Cryptophyceae, Dinophyceae, Raphidophyceae. In Flora Slodkowodna Polski, 4 (K. Starmach \& J. Sieminska, eds.). Polska Akademia Nauk, Institut Botaniki. Pánstwowe, Wydawnictwo Naukowe, Warsaw, 520p.

WILLÉN, E. 2003. Dominance patterns of planktonic algae in Swedish forest lakes. Hydrobiology 502:315-324.

YAMAGUCHI, H., NAKAYAMA, T., MURAKAMI, A. \& INOUYE, I. 2009. Phylogeny and taxonomy of the Raphidophyceae (Heterokontophyta) and Chlorinimonas sublosa gen. et sp. nov., a new marine sanddwelling raphidophyte. J. Plant. Res. www.springerlink.com/ index/8x92408j12p37753.pdf 